\title{
A SHORT NOTE ON THE CATCH COMPOSITION AND WEIGHT-LENGTH RELATIONSHIP OF TUNAS, BILLFISHES AND SHARKS OF NORTH BRAZIL
}

\author{
Mutsuo Asano-Filho ${ }^{I}$, Francisco Carlos Alberto Fonteles Holanda ${ }^{I}$; Francisco José da Silva Santos ${ }^{I}$, \\ Flávia Lucena ${ }^{2} \&$ Gisele de Sousa Lima Pantaleão ${ }^{I}$
}

${ }^{1}$ Centro de Pesquisa e Gestão de Recursos Pesqueiros da Região Norte e Instituto Brasileiro do Meio Ambiente e dos Recursos Naturais Renováveis (CEPNOR/IBAMA)

(Av. Tancredo Neves, 2501, Campus da UFRA, Bairro Montese, 66077-570, Belém, PA, Brasil) mutsuo7@hotmail.com.

\author{
${ }^{2}$ Universidade Federal do Pará \\ Departamento de Oceanografia \\ (Campus do Guama, Centro de Geociências, Belém, PA, Brasil)
}

The tuna longline fishery in the southwestern equatorial Atlantic, based in Brazilian ports, began using leased Japanese tuna longliners in 1956. This activity ceased in 1964 due to political and economical circumstances and reinitiated in 1983 (Hazin et al., 1990).

Information on the fishery, catch composition and biology of the tunas, billfishes and sharks inhabiting the equatorial Atlantic and waters adjacent to North Brazil are lacking. The tuna fishery has not been yet developed in this area and recently, a fishing company based in the city of Belém carried out cruises in the equatorial Atlantic in order to evaluate the potential of this fishery in the region.

This study is a short contribution to the knowledge of the species captured in waters adjacent to the North Brazilian coast. Its main objective is to describe the catch composition and the length-weight relationship of tunas, billfishes and sharks landed in Belém - Pa.

This is the first study of the basic biology of the tunas, billfishes and sharks in North Brazil.

A total of 10 research cruises were carried out in cooperation with a fishing company located at Belém during the period November 2000 to September 2002 along the North coast of Brazil between $06^{\circ} 30^{\prime} \mathrm{N}$ to $03^{\circ} 30^{\prime} \mathrm{S}$ and $049^{\circ} 30^{\prime} \mathrm{W}$ to $029^{\circ} 30^{\prime} \mathrm{W}$ (Fig. 1) under the scope of Project PROTUNA (Development of technologies for the exploitation of pelagics in North Brazil). The gear used was the longline described in Figure 2.

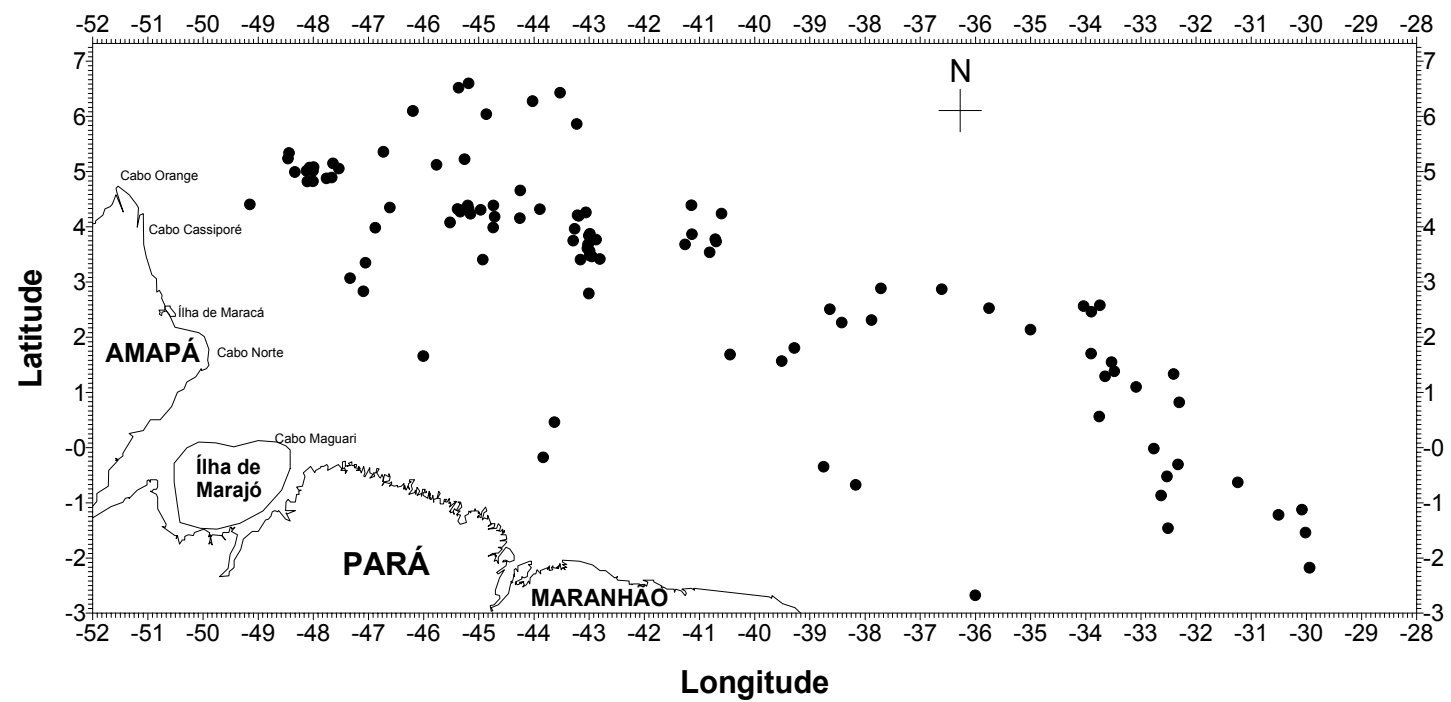

Fig. 1. Individual sets of the research cruises carried out in North Brazil from 2001 to 2002. 


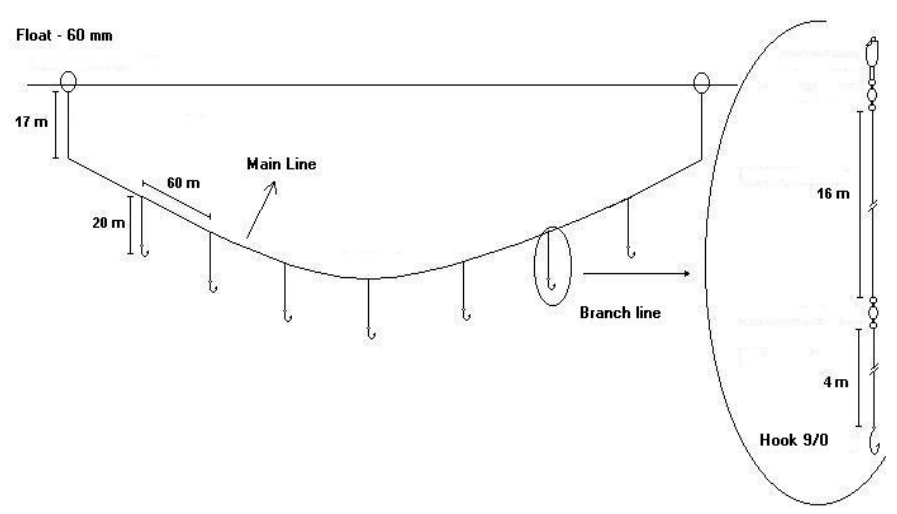

Fig. 2. The longline used for the tuna fishery in North Brazil.

A total of 12 species of tunas, billfishes and sharks were recorded (Table 1). Fish were identified at species level and the fork length FL $(\mathrm{cm})$, for tunas and sharks, and, upper jaw fork length (UJFL) for billfishes were measured and recorded. For all species the total weight TW (g) were also measured. Length compositions for all species (except Alopias since more than one species were identified and grouped in the same category) were analysed quarterly but values of all annual data were pooled together to overcome any inter-annual variability. The parametrical test ANOVA and the post-hoc Tukey Test were applied to test for differences considering the mean length of the studied species by season (Statistica 1996). Weightlength relationship $\left(\mathrm{W}=\mathrm{aL}^{\mathrm{b}}\right)$ were calculated for Xiphias gladius, Thunnus albacares, T.obesus, Tetrapturus albidus, Makaira nigricans, Prionace glauca, Carcharhinus maou, Isurus oxyrhincus and $C$. falciformis (number of observations larger than or equal to 25) using the predictive regression fitted by the least squares methodology (Zar, 1984).

Swordfish (Xiphias gladius) is responsible for $43 \%$ of the total catch (percentage in weight) (Table 2). The yellowfin tuna (Thunnus albacares) and the bigeye tuna (Thunnus obesus) are also well represented (24 and $16 \%$ of the catch in weight, respectively). Sharks (including at least 5 species) and 4 other species of billfishes comprised only 6 and $8 \%$ by weight, respectively. From 1983 to 1997, in Northeast Brazil, sharks (mainly the blue sharks and Carcharhinus sharks) dominated the catches representing $54 \%$ of the total catch (Hazin et al., 2000). From 1998, as in North Brazil, the fishery in this region targeted mainly the swordfish, and sharks were captured as by-catch (Santana, 2001).

The mean lengths of specimens of each species of tunas and billfishes were similar for each trimester, but in the case of the swordfish, white marlin, blue marlin and sailfish, differences between trimesters were noted (Table 3). For the swordfish, smaller individuals were found mainly towards the end of the year $\left(4^{\text {th }}\right.$ trimester). For the northeast Brazil, minimum size was reported during the third trimester of the year (Hazin, 2000). Twenty eight percent of all swordfish landed in North Brazil were composed of individuals smaller than the minimum size of capture established by ICCAT (The International Commission for the Conservation of Atlantic Tunas), i.e. $125 \mathrm{~cm}$ LJFL with $15 \%$ of tolerance or $119 \mathrm{~cm}$ LWFL with $0 \%$ of tolerance. For the fishery based on the northeast Brazil, around $2.7 \%$ of the captured individuals were smaller than the minimum size established (Marques, 2001). However this percentage may vary according to the sampling methodology: data obtained from sampling in the landing sites showed a higher percent of smaller individuals (probably due to the facility of storage for sampling) than the reported from the exportation spreadsheets, which showed larger individuals (probably due to the higher market value of the larger individuals). Individuals as large as 280 cm UJFL were also found in Northeast and Southern Brazil (Amorim et al., 1998; Marques, 2000). For the white marlin, blue marlin and sailfish, larger individuals were mainly reported in the second trimester.

Among the most abundant shark species landed in North Brazil, $47 \%$ of C. maou was under the length of first maturity $(180-190 \mathrm{~cm}$ TL, $151 \mathrm{~cm} \mathrm{FL}$ approximately; Lessa et al. 1999). Lessa et al., (1999) and Amorim et al. (1998) also reported a large amount of juveniles in the south-eastern Atlantic, suggesting that this area may be used as nursery for the species. In North Brazil, however, although mean lengths are smaller than the reported in Northeast Brazil, maximum size reported in the region $(300 \mathrm{~cm} \mathrm{TL})$ is superior than the registered in the Northeast $(250 \mathrm{~cm}$ TL). C. falciformis, showed significant differences in the mean length among samples caught in the trimesters of the year. The largest individuals were reported in the second trimester (Table 4). 
Table 1. Species recorded in the long line fishery carried out in North Brazil

\begin{tabular}{cccc}
\hline Common name & Scientific name & Common name & Scientific name \\
\cline { 2 - 3 } Yellowfin tuna & Thunnus albacares & Sailfish & Istiophorus albicans \\
& & & \\
Bigeye Tuna & Thunnus obesus & Blue shark & Prionace glauca \\
Albacore & Thunnus alalunga & Whitetip shark & Carcharhinus maou \\
Swordfish & Xiphias gladius & Silk shark & Carcharhinus falciformes \\
Blue marlin & Makaira nigricans & Mako & Isurus oxyrhincus \\
White Marlin & Tetrapturus albidus & Thintail thresher & Alopias sp.
\end{tabular}

Table 2 - Proportion in weight of tunas, billfishes and sharks captured in North Brazil.

\begin{tabular}{cccc}
\hline \hline Species & $\%$ & Species & $\%$ \\
\hline Thunnus albacares & 25 & Istiophorus albicans & 4 \\
Thunnus obesus & 16 & Prionace glauca & 1 \\
Thunnus alalunga & 1 & Carcharhinus maou & 3 \\
Xiphias gladius & 43 & Carcharhinus falciformis & 1 \\
Makaira nigricans & 3 & Isurus oxyrhincus & 1 \\
Tetrapturus albidus & 1 & Alopias sp & 1 \\
\hline
\end{tabular}

Table 3. Minimum, mean and maximum fork length of tunas and upper jaw - fork length $(\mathrm{m})$ of billfishes captured in North Brazil. $(\mathrm{n}=$ number of observations; $\mathrm{std}=$ standard deviation).

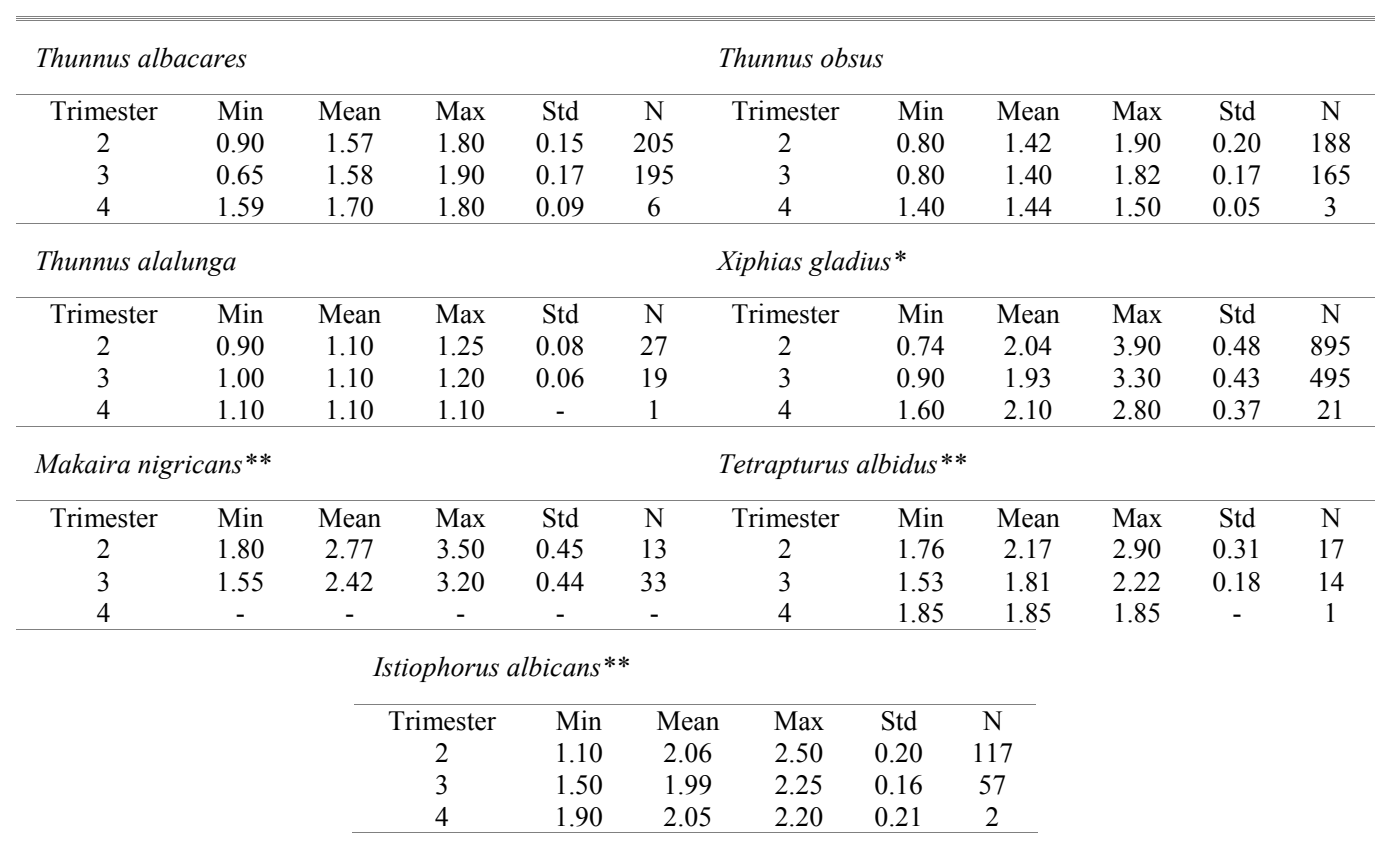

* the mean length in the forth trimester is significantly different when compared with the mean length reported in the second and third trimester $(\mathrm{P}<0.05)$.

**the mean length in the second trimester is significantly different when compared with the mean length reported in the third trimester $(\mathrm{P}<0.05)$ 
Table 4. Minimum, mean and maximum fork length $(\mathrm{m})$ of sharks captured in North Brazil. $(\mathrm{n}=$ number of observations; std $=$ standard deviation).

\begin{tabular}{|c|c|c|c|c|c|c|c|c|c|c|c|}
\hline \multicolumn{6}{|c|}{ Prionace glauca } & \multicolumn{6}{|c|}{ Carcharhinus maou } \\
\hline Trimester & Min & Mean & $\operatorname{Max}$ & Std & $\mathrm{N}$ & Trimester & Min & Mean & Max & Std & $\mathrm{N}$ \\
\hline 2 & 1.90 & 2.16 & 2.60 & 0.20 & 16 & 2 & 0.70 & 1.50 & 2.30 & 0.40 & 52 \\
\hline 3 & 1.30 & 1.97 & 2.30 & 0.31 & 10 & 3 & 0.63 & 1.36 & 3.00 & 0.47 & 40 \\
\hline 4 & - & - & - & - & - & 4 & 0.90 & 1.16 & 1.48 & 0.29 & 3 \\
\hline \multicolumn{6}{|c|}{ Carcharhinus falciformis* } & \multicolumn{6}{|c|}{ Isurus oxyrhincus } \\
\hline Trimester & Min & Mean & Max & Std & $\mathrm{N}$ & Trimester & Min & Mean & Max & Std & $\mathrm{N}$ \\
\hline 2 & 0.60 & 1.86 & 2.70 & 0.62 & 18 & 2 & 1.10 & 1.56 & 2.20 & 0,39 & 16 \\
\hline 3 & 0.60 & 1.08 & 1.90 & 0.42 & 18 & 3 & 1.00 & 1.57 & 2.00 & 0.33 & 8 \\
\hline 4 & 0.60 & 0.93 & 1.44 & 0.35 & 14 & 4 & 1.90 & 1.90 & 1.90 & - & 1 \\
\hline
\end{tabular}

* the mean length in the second trimester is significantly different when compared with the mean length reported in the third and forth trimester $(\mathrm{P}<0.05)$.

The relationship between body length and weight if of great importance in fishery biology not only for the estimates of biomass obtained from analytical models but also the parameter $b$ of the relationship has also an important biological meaning, indication the rate of weight gain relative to growth (Gulland, 1983; Frota et al., 2004). Length-weight relationship for some tuna and sharks is available for the northeast and central Brazilian coast (Hazin et al., 1990; Lessa et al., 1999; Frota et al., 2004). Weightlength relationship (TW x FL for sharks and tunas and TW $x$ UJFL for billfishes) is shown in Table 5.

Concluding, it was verified that swordfish dominated the catch (by weight), followed by the yellowfin and bigeye tunas the tunas showed little seasonality in size, but the bill fishes and sharks presented a marked seasonal size variation almost half of the exemplars of Carcharhimus maou captured was under the first maturity length.

\section{REFERENCES}

Amorin, A. F.; Arfelli, C. A. \& Fagundes, L. 1998. Pelagic elasmobranchs caught by longliners off southern Brazil during 1974-1997: an overview. Mar. Fresh. Res., 49:621-632.

Frota, L. O.; Costa, P. A. S. \& Braga, A. C. 2004. Lengthweight relationships of marine fishes form the central Brazilian coast. Naga, 27: 20-26.

Gulland, J. A. 1983. Fish stock assessment: a manual of basic methods. Rome, FAO/Wiley Seried on Food and Agriculture. v. 1:233p.

Hazin, F. H.; Couto, A. A.; Ishino, M. Otsuka, K. \& KIHARA, K. 1990. Morphometric description of the blue shark, Prionace glauca, form the south-western Equatorial Atlantic. J. Tokyo Univ. Fish., 78(2):137144.

Hazin, F. H., Lessa, R. P.; Couto, A.A. Kihara, K. \& Otsuka, K. 1990. Distribution and abundance of pelagic sharks in the south-western equatorial Atlantic. J. Tokyo Univ. Fish., 77(1):51-64.

Table 5. Weight-length relationship of tunas, billfishes and sharks captured in North Brazil.

\begin{tabular}{|c|c|c|c|c|}
\hline Species & a & $\mathrm{b}$ & $\mathrm{r}$ & $\mathrm{n}$ \\
\hline Thunnus albacares (TW $x F L)$ & 0.0002 & 2.44 & 0.91 & 407 \\
\hline Thunnus obesus (TW $x$ FL) & 0.0004 & 2.34 & 0.80 & 357 \\
\hline Tetrapturus albidus (TW x UJFL) & 0.0000007 & 3.34 & 0.83 & 33 \\
\hline Makaira nigricans (TW $x$ UJFL) & 0.000006 & 3.16 & 0.88 & 47 \\
\hline Xiphias gladius (TW $x$ UJFL) & 0.00002 & 2.68 & 0.91 & 1412 \\
\hline Prionace glauca $(T W \times F L)$ & 0.0009 & 2.03 & 0.66 & 26 \\
\hline Carcharhinus maou (TW $x$ FL) & 0.0003 & 2.27 & 0.85 & 95 \\
\hline Isurus oxyrhincus (TW $x F L)$ & 0.0002 & 2.34 & 0.82 & 25 \\
\hline Carcharhinus falciformis (TW $x F L)$ & 0.000006 & 2.99 & 0.96 & 42 \\
\hline
\end{tabular}


Hazin,, H. G. 2000. Distribuição, abundância relativa e biologia reprodutiva do espadarte, Xiphias gladius (Linnaeus, 1758), capturado no Atlântico Sudoeste Equatorial. Monografia de Graduação. Universidade Federal Rural de Pernambuco. 54 p.

Lessa, R.; Paglerani, R. \& Santana, F. M. 1999. Biology and morphometry of the oceanic whitetip shark, Carcharhinus longimanus (Carcharhinidae), off Northeastern Brazil. Cybium, 23 (4): 353-368.

STATISTICA. 1996. Statsoft, INC., Tulsa, USA.

Zar, J. H. 1984. Biostatistical analysis. $2^{\text {nd }}$ ed. New Jersey, Prentice Hall.
Sources of Unpublished Material

Marques, C. C. 2001. Composição e estrutura populacional do espadarte (Xiphias gladius, Linnaeus, 1758) no Atlântico Sudoeste Equatorial: análise da distribuição de freqüência de comprimento e caracterização genética da população. M.Sc. Thesis. Universidade Federal de Pernambuco. 59p.

Santana, F .M. 2001. Taxas de crescimento intríseco de tubarões: uma contribuição para o plano de manejo de elasmobrânquios no Brasil. M.Sc. Thesis. Universidade Federal de Pernambuco. 75p.

Manuscript received 18 March 2004; revised 29 September 2004; accepted 20 December 2004) 